слід розглядати у взаємозв'язку 3 оточуючим середовищем, забезпечуючи можливу стабільність внутрішнього мікроклімату та захист від зовнішніх кліматичних впливів. Реставраційні методики, що застосовуються на пам'ятці, повинні максимально зберігати іiі автентичність, а при виборі реставраційних матеріалів враховуватися їх вплив на авторську матеріальну структуру.

\title{
Література:
}

1. Переписка с Советом министров УССР о состоянии охраны памятников культуры в УССР за 1946 год. ЦДАВО Украӥни (Центр. держ. архів вищих органів влади), Ф. 4762. Оп. 1. Спр. 77.

2. Плющ О. Ф. Рекомендации по методике закрепления пигментов древних фресок / за ред. Ю. Ф. Скорикова. Київ : НИИТАГ, 1961. 24 с.

3. Ребрикова Н. Л. Биология в реставрации. Москва : РИО ГосНИИР, 1999. $184 \mathrm{c}$.

4. Зайцева В., Чобітько О. Проблеми збереження та реставрації пам'яток архітектури та монументального живопису Національного Києво-Печерського історико-культурного заповідника. Реставращія пам'яток архітектури в умовах високого рівня трунтових вод та підвищеної вологості інтер'єрів: матеріали міжн. наук.-практ. конф. (Київ, 24-25 жовтня 2019 р.). Київ, 2019. С. 49-57.

DOI https://doi.org/10.30525/978-9934-26-004-9-47

\section{ПРЕДМЕТНИЙ СВІТ ОЛЕКСАНДРА ОСМЬОРКІНА ЯК ЗАСІБ КОМПОЗИЦІЙНО-СМИСЛОВОЇ ОРГАНІЗАЦЇ̈ КАРТИННОГО ПРОСТОРУ}

\author{
Кириченко О. I. \\ кандидат мистеитвознавства, доиент, \\ дочент кафедри образотворчого мистецтва та дизайну \\ Центральноукраїнського державного педагогічного університету \\ імені Володимира Винниченка \\ м. Кропивнииький, Украӥна
}

В живописі різних епох предмети і речі часто з'являлися як концепти, які відображають певні естетичні позиції i набувають смислового значення - від сакрального до емблематичного, знакового, що змінює загальновизнаний смисл речей i розкриває цінності власного життя художника в конкретний період. Мистецтво XX століття не $\epsilon$ винятком у 
ставленні до предметного світу. Особливо значущим у процесі наділення змістом предмету в мистецтві представляється жанр натюрморту, на який звернули увагу художники-новатори. Серед творчих об'єднань, що надали цінності даному жанру в першій чверті XX століття, був «Бубновий валет», з яким тісно пов'язаний мистецький шлях О. Осмьоркіна. Митець не залишився «бубнововалетцім» назавжди, протягом свого творчого життя він освоював різні художні системи та жанри живопису, зберігаючи ціннісно позначене відношення до предметного оточення людини, до навантаження речі роллю символу та перетворення предмету у виразний елемент композиції. Вже при першому наближенні можна побачити, що в картинах Осмьоркіна існує власна закодована художня реальність, яка демонструє специфіку особистісної реакції на переживання подій часу через знакові образи-речі.

Дослідження творчості О. Осмьоркіна давно потребує поглибленого підходу до його живопису. Публікацій, що присвячені художнику, небагато, можна згадати нарис С. Мелікадзе і П. Сисоєва (1939), каталог групової виставки (1940), який склала Е. В. Членова і де ім'я Осмьоркіна лише згадується, статті О. Дейнеки і Л. Акімової 1959 і 1960 років та спогади про Осмьоркіна-педагога його учня А. Нікіча. Етапи творчого шляху художника виявлені у невеликій книжці Л. А. Усольцевої із серії «Масова бібліотека з мистецтва» (1978). Сдиним змістовним джерелом, що дозволяє отримати уявлення про особистість i художньо-естетичну позицію майстра, є «Роздуми про мистецтво. Листи. Критика. Спогади сучасників» (1981). У 1980-х видані два каталоги персональних виставок художника зі статтею I. С. Болотіної i А. В. Щербакова, яка була опублікована ще у вище зазначеній книзі. Коли в Кіровограді (нині Кропивницький) в Україні, звідки походить Осмьоркін, був створений його художньо-меморіальний музей, певні особливості творчості живописця розглядалися співробітником музею А. М. Надєждіним. Однак до сьогоднішнього дня не відбулося повного осмислення творчої спадщини майстра з ії складнощами, суперечностями, аналізом художньоестетичних концепцій. Звернення до деяких аспектів, що складають багатогранний художній світ О. Осмьоркіна, допоможуть зрозуміти відчуття митцем епохи та власного місця у нових реаліях життя.

Метою даної статті є визначення ролі предметного світу в творчості Осмьоркіна, що набуває у художника важливого естетичного i смислового значення та впливає на композиційну організацію картинного простору. Дана мета реалізується за допомогою аналітичного, семіотичного та узагальнюючого дослідницьких методів, кожний з яких окремо і всі вони разом дозволяють розкрити зміст творів О. Осмьоркіна через зображені предмети та побудову з їх допомогою композиційного простору картини. 
Світ речей - особлива тема у творчості Осмьоркіна, в ній простежуються різні естетичні вподобання. Предметний світ виступає то як мотив композиції, то як тема картини, завжди маючи різні змістовні конотації. Орієнтир митця на співпрацю 3 художнім об'єднанням «Бубновий валет» пояснює його зацікавленість не тільки новітніми живописними відкриттями, але й жанром натюрморту. Відношення «бубнововалетців» до предмету як структурному феномену, що організує композицію, перетворювало сам предмет на річ, яка «стає осередком певного світогляду, набуваючи крім буквального більш широке символічне значення» [3, с. 11$]$.

У своїх ранніх, сезаннівських за манерою виконання, творах Осмьоркін зображує ті речі, які дозволяють йому втілити живописні концепції «бубнововалетців». Музичні інструменти в «Натюрморті 3 бандурою» (1921; Державний Російський музей, Санкт-Петербург, далі ДРМ) цікавлять автора з боку пластичної виразності та живописного ліплення форми. Проте вибір саме струнних інструментів вказує на добре їх знання, адже Осмьоркін в юні роки грав на мандоліні, коли брав участь у домашніх виставах, що практикувалися в будинку його дядька архітектора Я. В. Паученка. Через цілий ряд ранніх натюрмортів червоною ниттю проходить бажання Осмьоркніа передати засобами кольору ліплення форми та конструкцію, матеріальність предметів, при цьому він не робіть акцентів на даній якості, а більш тонко працює 3 колоритом, як це можна побачити в «Натюрморті 3 палітрою» (1920; Тульський художній музей), «Натюрморті 3 годинником» (1920; Державний музей образотворчих мистецтв Республіки Татарстан), «Натюрморті з черепом» (1921; ДРМ), «Натюрморті з білою піалою» (1921; ДРМ), «Натюрморті 3 лубочною картинкою» (1921; Приватна колекція). Предмети, обрані для натюрмортів, завжди значимі для художника. Він звертається до таких речей, які натякають на власні інтереси та відчуття плину часу. Так, череп, що став образом одного 3 натюрмортів, як би нагадує давню гру в домашньому театрі ролі Гамлета, невипадково драперія розташована в композиції як театральна куліса. Атрибути мистецтва - палітра, лубочна картинка, пензлі вказують на творчу діяльність автора, але вони з'являються в Осмьоркіна не дуже часто. Особливу роль відіграє дзеркало, яке іноді присутнє в композиціях. Дзеркало завжди має властивість бінарності, воно як би покликане здійснювати перенесення смислових значень [1, с. 27], 3 одного боку, а з іншого - вказує на присутність третьої особи [1, с. 30] i тим самим поглиблює позицію автора-оповідача. Воно ж розширює простір картини.

Згодом у натюрмортах художника орієнтованість у бік вирішення композиційно-просторових та колористичних завдань стає головною 184 
метою на шляху прагнення створити велику картину. Художник багато працює в 1940-кі роки над пейзажем, натюрмортом, портретом, пише їх у стилістиці імпресіонізму, що не сприймалося тогочасною критикою як позитивний момент. Саме в ці часи одним з улюблених натюрмортних мотивів Осмьоркіна постає вікно, на підвіконні якого розташовані різні речі. Мотив вікна опинився популярним майже у всіх митців, що мали відмовитися від «формалізму», з 1930-х років. Осмьоркін бачить у ньому можливість відобразити свій душевний стан і настрій та вказати на конкретні події свого життя. Такими інтонаціями пронизані «Асторія. Номер 103» (1945; Художньо-меморіальний музей О. Осмьоркіна, Кропивницький - далі ХММО), «Вид із вікна на Троїце-Сергієву лавру» (1947; Красноярський художній музей ім. В. І. Сурікова). У кожній роботі зображені на підвіконні предмети мають особистісне значення для автора (букети садових i польових квитів та горшки 3 кімнатними квітами, предмети для гоління i дзеркало, чарки, скульптура лева, пляшки). Художник пише самі різні букети та квіти, опиняючись і тут в одному ряду з колегами по цеху [3].

Річ, зображена поряд з людиною, семантизується у Осмьоркіна поновому, набуває інших смислів і функцій. У «Портреті художника Михайла Микитича Авєтова» (1924; ДРМ) митець прагне розкрити характер моделі, співвіднести музичний інструмент 3 тонко організованою творчою натурою зображеного. В «Циганці-солістці» (1927; Тамбовська обласна картинна галерея) гітара з'являється як би осторонь, у глибині композиції, в тіні фігури - вона висить на стіні за спиною моделі, яка занурена у свої думки. Мовчання як лейтмотив композиції свідчить про стан самого автора, який раптом усвідомив необхідність зжити «формалізм» у творчості [2, с. 66].

Коли Осмьоркін створює портрет близької йому людини, він концентрує увагу на моделі і одночасно вводить у композицію невеличкі деталі, якими підтримує образ. На підвіконні в роботі «Портрет Анни Ахматової. Біла ніч» (1939-1940; Державний літературний музей, Москва) стоїть скромний букетик, який підкреслює жіночість та ліричність героїні. Цікаво зіставлені букети і модель у роботі «Профіль і квіти (В майстерні художника)» (1946; Державна Третьяковська галерея, Москва). Предмети і речі можуть у Осмьоркіна виступати й майже алегоричними символами, за допомогою яких автор шифрує важливі для себе смисли. В картині «Зелене пальто» (1947; ХММО) головною героїнею є дружина художника, яка зображена за перешиванням пальто. Проте автор полотна висуває на передній план саме пальто, яке постає знаком власної присутності митця у просторі кімнати. Всі інші речі, якими заповнений кут кімнати, що показує художник, призвані підтримувати цю умовну присутність митця. Він не бажає зображати 
себе - тоді картина набула би іншого змісту. Осмьоркін таким чином вказує на прагнення закритись у внутрішньому просторі, не впускати в нього чужих, можливо, знайти вихід із складної ситуації, в якій він опинився в цей період життя. I тут певну роль відіграє дзеркало, яке неодноразово з'являлося в натюрмортах. Відображення в дзеркалі - це як би інша реальність, своєрідна гра, яка здатна трансформувати зміст оповідання.

Таким чином, звернення Осмьоркіна до світу предметів і наділення їх символічними значеннями відображає полімодальність мислення митця. Розглядаючи місце і роль конкретних предметів у просторі картини, ми представляємо цілісну картину світу живописця, в якій немає випадкових образів, та розуміємо композиційні акценти в картинному просторі.

\title{
Література:
}

1. Злыднева Н. В. Визуальный нарратив: опыт мифопоэтического прочтения. Москва: Индрик, 2013. 360 с.

2. Осмеркин. Размышления об искусстве. Письма. Критика. Воспоминания современников. Москва: Советский художник, 1981. 400 с.

3. Хузина Т. Е. Предметный мир в советской живописи 1930-х гг.: семантический анализ. Атореф. дисс. ... канд. искусствов-я: 17.00.09. Санкт-Петербург, 2009. 24 с.

DOI https://doi.org/10.30525/978-9934-26-004-9-48

\section{КАЗИМИР МАЛЕВИЧ ЖІНОЧИЙ ТОРС № 1: ФОРМА І КОЛІР}

\author{
Коваленко С. Г. \\ аспірант кафедри мистецтвознавчої експертизи \\ Національної академії керівних кадрів культури і мистецттв \\ м. Київ, Україна
}

Творча особистість Казимира Малевича в історії образотворчого мистецтва $є$ уособленням митця-новатора, філософа, що сформувався як художник на зламі епох і пошуків нових шляхів у мистецтві, синтезу культур, соціально-економічних потрясінь. Як інші художники авангарду, митець вже не зображував пророків і революціонерів, а сам проголошував себе провісником і руйнівником у мистецтві. В умовах інтенсивної мутації культурного генотипу зросла роль творчої ініціативи, 